BIOLOGICAL INVADERS IN INLAND WATERS:

PROFILES, DISTRIBUTION, AND THREATS 


\section{INVADING NATURE - \\ SPRINGER SERIES IN INVASION ECOLOGY}

Volume 2

Series Editor: JAMES A. DRAKE

University of Tennessee,

Knoxville, TN, U.S.A. 


\title{
Biological invaders in inland waters: Profiles, distribution, and threats
}

\author{
Edited by
}

FRANCESCA GHERARDI

算 Springer 
A C.I.P. Catalogue record for this book is available from the Library of Congress.

ISBN 978-1-4020-6028-1 (HB)

ISBN 978-1-4020-6029-8 (e-book)

Published by Springer,

P.O. Box 17, 3300 AA Dordrecht, The Netherlands.

www.springer.com

Printed on acid-free paper

All Rights Reserved

(C) 2007 Springer

No part of this work may be reproduced, stored in a retrieval system, or transmitted in any form or by any means, electronic, mechanical, photocopying, microfilming, recording or otherwise, without written permission from the Publisher, with the exception of any material supplied specifically for the purpose of being entered and executed on a computer system, for exclusive use by the purchaser of the work. 


\section{Contents}

Contributors $\quad x i$

Foreword xxiii

Preface $\quad$ xxv

Introduction 1

1 Biological invasions in inland waters: an overview 3

Francesca Gherardi

Distribution of invaders

2 Invasive crustaceans in European inland waters

David M. Holdich and Manfred Pöckl

3 Non-indigenous freshwater crabs in France: a new occurrence of a potamid near Nice

Pierre Y. Noël and Danièle Guinot

4 Status and ecosystem interactions of the invasive Louisianan red swamp crayfish Procambarus clarkii in East Africa

John Foster and David Harper 
5 Non-indigenous freshwater molluscs and their distribution in Italy

Simone Cianfanelli, Elisabetta Lori, and Marco Bodon

6 Non-indigenous animal species naturalized in Iberian inland waters

Emili García-Berthou, Dani Boix, and Miguel Clavero

7 An overview of the natural history of non-indigenous amphibians and reptiles

Riccardo Scalera

8 The red-eared slider (Trachemys scripta elegans) in Asia: a review

Neil F. Ramsay, Pek Kaye Abigayle Ng, Ruth M. O'Riordan, and Loke Ming Chou

9 Semiaquatic mammals introduced into Italy: case studies in biological invasion

Sandro Bertolino and Piero Genovesi

10 Invasions by plants in the inland waters and wetlands of Africa

Geoffrey W. Howard and Florence W. Chege

11 Non-indigenous aquatic and semiaquatic plant species in France

Gabrielle Thiébaut

Profiles of invaders

12 Ecological traits of aquatic NIS invading Austrian fresh waters

Leopold Füreder and Manfred Pöckl 
13 Growth and reproduction of the goldfish Carassius auratus: a case study from Italy

Massimo Lorenzoni, Massimiliano Corboli, Lucia Ghetti, Giovanni Pedicillo, and Antonella Carosi

14 Epigenetic context in the life history traits of the round goby, Neogobius melanostomus

Mária Balážová-L'avrinčíková and Vladimír Kováč

15 Growth and life history traits of introduced pumpkinseed (Lepomis gibbosus) in Europe, and the relevance to its potential invasiveness

Gordon H. Copp and Michael G. Fox

16 The biological flexibility of the pumpkinseed: a successful colonizer throughout Europe

Jozef Tomeček, Vladimír Kováč, and Stanislav Katina

\section{Patterns and pathways of invasions}

17 Marine vs. freshwater invaders: is shipping the key vector for species introductions to Europe?

Stephan Gollasch

18 Modeling biological invasions of inland waters

Hugh J. MacIsaac, Leif-Matthias Herborg, and Jim R. Muirhead

19 Biomonotony: definition and assessment for macroinvertebrates in European running waters

Jean-Nicolas Beisel and Simon Devin

20 Genetics and invasion biology in fresh waters: a pilot study of Procambarus clarkii in Europe

Silvia Barbaresi, Francesca Gherardi, Alessio Mengoni, and Catherine Souty-Grosset 
21 Do estuaries act as saline bridges to allow invasion of new freshwater systems by non-indigenous fish species?

J. Anne Brown, Dawn M. Scott, and Rod W. Wilson

22 Which factors determine non-indigenous fish dispersal?

A study of the red piranha in tropical Brazilian lakes

Anderson O. Latini and Miguel Petrere Jr.

23 The relationship between biodiversity and invasibility in central Swedish lakes invaded by Elodea species

Daniel Larson and Eva Willén

Impacts of invaders

24 Measuring the impact of freshwater NIS: what are we missing?

Francesca Gherardi

25 Invasion of the Baltic Sea basin by the Ponto-Caspian amphipod Pontogammarus robustoides and its ecological impact

Kestutis Arbačiauskas and Simona Gumuliauskaite

26 Changes in the aquatic systems of north-eastern Europe after invasion by Gmelinoides fasciatus

Nadezhda A. Berezina

27 The predatory impact of Dikerogammarus villosus on fish

Sandra Casellato, Alessandra Visentin, and Giovanni La Piana

28 Understanding the impact of invasive crayfish

Francesca Gherardi

29 Predation of invasive crayfish on aquatic vertebrates: the effect of Procambarus clarkii on fish assemblages in Mediterranean temporary streams

Maria Ilhéu, João Manuel Bernardo, and Sílvia Fernandes 
30 Assessing the trophic ecology of crayfish: a case study of the invasive Procambarus clarkii

María Crehuet, Paloma Alcorlo, Miguel Angel Bravo-Utrera,

Angel Baltanás, and Carlos Montes

31 Introduction and spread of crayfish (Parastacidae)

in Western Australia and their potential to displace indigenous species

Jessica Lynas, Andrew Storey, and Brenton Knott

32 The zebra mussel Dreissena polymorpha:

reproduction and competition with the sponge

Ephydatia fluviatilis

Tisza Lancioni and Elda Gaino

33 Seasonal effects on the antioxidant response and metal accumulation of Dreissena polymorpha

Antonia C. Elia, Ambrosius J. M. Dörr, Marino Prearo, and Maria C. Abete

\section{Managing invasions}

34 Towards a European strategy to halt biological invasions in inland waters

Piero Genovesi

35 A risk assessment of biological invasions in the inland waterways of Europe: the Northern Invasion Corridor case study

Vadim E. Panov, Yury Yu. Dgebuadze, Tamara A. Shiganova, Andrew A. Filippov, and Dan Minchin

36 Logistics of shipboard and dockside testing of ballast water treatment systems in the United States

David A. Wright 
37 Virtues and shortcomings of EU legal provisions for managing NIS: Rana catesbeiana and Trachemys scripta elegans as case studies

Riccardo Scalera

38 Problems and opportunities managing invasive Bullfrogs: is there any hope?

Michael J. Adams and Christopher A. Pearl

Concluding remarks

39 A role for scientists

Francesca Gherardi

Index

General keywords

Families, orders

Geographical names

713

Taxa common names

721

Species index 


\section{Contributors}

Maria C. Abete

Experimental Zooprofilactic Institute of Piedmont, Liguria and Valle d'Aosta, Via Bologna 148, 10154 Torino, Italy

mariacesarina.abete@izsto.it

Michael J. Adams

USGS Forest and Rangeland Ecosystem Science Center, 3200 SW Jefferson Way, Corvallis, OR 97331, USA

michael_adams@usgs.gov

Paloma Alcorlo

Department of Ecology, Autonomous University of Madrid, c/ Darwin 2, 28049 Madrid, Spain

paloma.alcorlo@uam.es

Kęstutis Arbačiauskas

Institute of Ecology, Vilnius University, Akademijos 2, LT-08412 Vilnius-21, Lithuania

arbas@ekoi.lt

Mária Balážová-L'avrinčíková

Comenius University, Faculty of Natural Sciences, Department of Ecology, Mlynská dolina B-2, 84215 Bratislava, Slovakia

lavrincikova@fns.uniba.sk 
Angel Baltanás

Department of Ecology, Autonomous University of Madrid, c/ Darwin 2, 28049 Madrid, Spain

angel.baltanas@uam.es

\section{Silvia Barbaresi}

Department of Animal Biology and Genetics, University of Firenze, Via Romana 17, 50125 Firenze, Italy

silvia.barbaresi@unifi.it

Jean-Nicolas Beisel

LIEBE, CNRS, Campus Bridoux, Paul Verlain University, Metz, Avenue du Général Delestraint, 57070 Metz, France

beisel@univ-metz.fr

Nadezhda A. Berezina

Laboratory of Freshwater and Experimental Hydrobiology, Zoological Institute, Russian Academy of Sciences, Universitetskaya emb. 1, 199034 St. Petersburg, Russia

nber@zin.ru

João M. Bernardo

Department of Ecology, University of Évora, Colégio Luis Verney, Rua Romão Ramalho, 7000-671 Évora, Portugal

jmb@uevora.pt

Sandro Bertolino

DI.VA.P.R.A., Laboratory of Entomology and Zoology, Via L. da Vinci 44, 10095 Grugliasco, Italy

sandro.bertolino@unito.it

\section{Marco Bodon}

Department of Environmental Sciences, University of Siena, Via Mattioli 4, 53100 Siena, Italy mabodon@tin.it 
Dani Boix

Institute of Aquatic Ecology, University of Girona, Campus Montilivi, 17071 Girona, Spain

dani.boix@udg.es

\section{Miguel Angel Bravo-Utrera}

Biological Reserve of Doñana, 21760, Matalascañas, Huelva, Spain mabravo@ebd.csic.es

\section{J. Anne Brown}

School of Biosciences, Hatherly Laboratories, Prince of Wales Road, University of Exeter, Exeter, EX4 4PS, UK

j.a.brown@exeter.ac.uk

\section{Antonella Carosi}

Department of Cellular and Environmental Biology, University of Perugia, Via Elce di Sotto, 06123 Perugia, Italy

faunaittica@provincia.terni.it

\section{Sandra Casellato}

Department of Biology, University of Padova, Via U. Bassi 58/BIG, 35121 Padova, Italy sandra.casellato@unipd.it

Florence W. Chege

Eastern Africa Regional Programme, IUCN - The World Conservation Union, P.O. Box 68200, Nairobi, 00200, Kenya

florence.chege@iucn.org

\section{Loke Ming Chou}

Department of Biological Sciences, National University of Singapore, 14 Science Drive 4, 117543, Singapore

dbsclm@nus.edu.sg 
Simone Cianfanelli

Museum of Natural History, Zoological Section “La Specola”, University of Firenze, Via Romana 17, 50125 Firenze, Italy

simone.cianfanelli@unifi.it

\section{Miguel Clavero}

Institute of Aquatic Ecology, University of Girona, Campus Montilivi, 17071 Girona, Spain

miguel.clavero@udg.es

Gordon H. Copp

Centre for Environment, Fisheries \& Aquaculture Science (CEFAS), Salmon \& Freshwater Team, Pakefield Road, Lowestoft, NR33 OHT, UK

gordon.copp@cefas.co.uk

\section{Massimiliano Corboli}

Department of Cellular and Environmental Biology, University of Perugia, Via Elce di Sotto, 06123 Perugia, Italy

emmeci@angelfire.com

\section{María Crehuet}

Department of Ecology, Autonomous University of Madrid, c/ Darwin 2, 28049 Madrid, Spain

maria.crehuet@uam.es

\section{Simon Devin}

LIEBE, CNRS, Campus Bridoux, Paul Verlain University, Metz, Avenue du Général Delestraint, 57070 Metz, France

devin@univ-metz.fr

\section{Yury Yu. Dgebuadze}

Severtsov Institute of Ecology and Evolution of the Russian Academy of Science, Leninsky Prospect 33, 117071 Moscow, Russia dgebuadze@sevin.ru

Ambrosius J. M. Dörr

Department of Cellular and Environmental Biology, University of Perugia, Via Elce di Sotto, 06123 Perugia, Italy 
Antonia C. Elia

Department of Cellular and Environmental Biology, University of Perugia, Via Elce di Sotto, 06123 Perugia, Italy

elia@unipg.it

\section{Sílvia Fernandes}

Department of Ecology, University of Évora, Colégio Luis Verney, Rua Romão Ramalho, 7000-671 Évora, Portugal

smariaf@hotmail.com

\section{Andrew A. Filippov}

Faculty of Biology and Soil Science, St. Petersburg State University, Universitetskaya nab. 7-9, 199034 St. Petersburg, Russia

filippov@ecopro.spb.ru

\section{John Foster}

Environment Agency, Saxon House, Little High Street, Worthing, West Sussex, BN11 1DH, UK

john.foster@environment-agency.gov.uk

Michael G. Fox

Environmental and Resource Studies Program and Department of Biology, Trent University, Peterborough, Ontario, K9J 7B8, Canada

mfox@trentu.ca

\section{Leopold Füreder}

River Ecology and Freshwater Fauna Laboratory, Institute of Ecology, LeopoldFranzens University, Technikerstr. 25, 6020 Innsbruck, Austria

leopold.fuereder@uibk.ac.at

\section{Elda Gaino}

Department of Cellular and Environmental Biology, University of Perugia, Via Elce di Sotto, 06123 Perugia, Italy

gaino@unipg.it

\section{Emili García-Berthou}

Institute of Aquatic Ecology, University of Girona, Campus Montilivi, 17071 Girona, Spain emili.garcia@udg.es 
Piero Genovesi

National Institute of Wild Fauna (INFS), Via Ca' Fornacetta 9, 40064 Ozzano Emilia, Italy

piero.genovesi@infs.it

Francesca Gherardi

Department of Animal Biology and Genetics, University of Firenze, Via Romana 17, 50125 Firenze, Italy

francesca.gherardi@unifi.it

\section{Lucia Ghetti}

Umbria Region, Servizio Programmazione Forestale, Faunistico-Venatoria ed Economia Montana, Via M. Angeloni 61, 06124 Perugia, Italy lghetti@yahoo.it

\section{Stephan Gollasch}

GoConsult, Grosse Brunnenstr. 61, 22763 Hamburg, Germany http://www.gollaschconsulting.de

\section{Danièle Guinot}

National Museum of Natural History, Department of Habitats and Aquatic Populations, P.O. Box 53, 57 rue Cuvier, F-75231 Paris cedex 05, France guinot@mnhn.fr

\section{Simona Gumuliauskaite}

Centre for Ecology and Environmental Sciences, Vilnius University, Čiurlionio 21/27, LT-07119 Vilnius-10, Lithuania

simona.gumuliauskaite@gf.vu.It

David Harper

Department of Biology, University of Leicester, University Road, Leicester, LE1 7RH, UK

dmh@leicester.ac.uk 


\section{Leif-Matthias Herborg}

Great Lakes Institute for Environmental Research, University of Windsor, Windsor, Ontario, N9B 3P4, Canada

lherborg@uwindsor.ca

\section{David M. Holdich}

East Midlands Environmental Consultants, The Old Ragged School, Brook Street, Nottingham, NG1 1EA, UK

david.holdich@ntlworld.com

\section{Geoffrey W. Howard}

Eastern Africa Regional Programme, IUCN - The World Conservation Union, P.O. Box 68200, Nairobi, 00200, Kenya

geoffrey.howard@iucn.org

\section{Maria Ilhéu}

Departament of Ecology, University of Évora, Colégio Luis Verney, Rua Romão Ramalho, 7000-671 Évora, Portugal

milheu@uevora.pt

\section{Stanislav Katina}

Comenius University, Faculty of Mathematics, Physics and Informatics, Department of Probability and Mathematical Statistics, Mlynská dolina, 84248 Bratislava, Slovakia

katina@fmph.uniba.sk

\section{Brenton Knott}

School of Animal Biology (M092), The University of Western Australia, 35 Stirling Highway, Crawley, W.A. 6009, Australia bknott@cyllene.uwa.edu.au

\section{Vladimír Kováč}

Comenius University, Faculty of Natural Sciences, Department of Ecology, Mlynská dolina B-2, 84215 Bratislava, Slovakia kovac@fns.uniba.sk 
Tisza Lancioni

Department of Cellular and Environmental Biology, University of Perugia, Via Elce di Sotto, 06123 Perugia, Italy

t.lancioni@arpa.umbria.it

\section{Giovanni La Piana}

Department of Biology, University of Padova, Via U. Bassi 58/BIG, 35121 Padova, Italy

giovannilapiana@virgilio.it

\section{Daniel Larson}

Department of Environmental Assessment, Swedish University of Agricultural Sciences, P.O. Box 7050, 75007 Uppsala, Sweden

daniel.larson@ma.slu.se

\section{Anderson O. Latini}

UNILESTEMG, University Centre of Eastern Minas Gerais, CCB Campus Bom Retiro, Rua Bárbara Heliodora, 725 Bairro Bom Retiro, Ipatinga, 35160-215 MG, Brazil

aolatini@bol.com.br

\section{Massimo Lorenzoni}

Department of Cellular and Environmental Biology, University of Perugia, Via Elce di Sotto, 06123 Perugia, Italy

lorenzon@unipg.it

\section{Elisabetta Lori}

Museum of Natural History, Zoological Section "La Specola”, University of Firenze, Via Romana 17, 50125 Firenze, Italy

elisabetta.lori@unifi.it

\section{Jessica Lynas}

School of Animal Biology (M092), The University of Western Australia, 35 Stirling Highway, Crawley, W.A. 6009, Australia jlynas@cyllene.uwa.edu.au 
Hugh J. MacIsaac

Great Lakes Institute for Environmental Research, University of Windsor, Windsor, Ontario, N9B 3P4, Canada

hughm@uwindsor.ca

\section{Alessio Mengoni}

Department of Animal Biology and Genetics, University of Firenze, Via Romana 17, 50125 Firenze, Italy

alessio.mengoni@unifi.it

\section{Dan Minchin}

Marine Organism Investigations, 3 Marina Village, Ballina, Killaloe, County Clare, Ireland

minchin@indigo.ie

\section{Carlos Montes}

Department of Ecology, Autonomous University of Madrid, c/ Darwin 2, 28049 Madrid, Spain

carlos.montes@uam.es

Jim R. Muirhead

Great Lakes Institute for Environmental Research, University of Windsor, Windsor, Ontario, N9B 3P4, Canada

muirhe1@uwindsor.ca

\section{Pek Kaye Abigayle $\mathrm{Ng}$}

Department of Biological Sciences, National University of Singapore, 14 Science Drive 4, 117543, Singapore

g0306158@nus.edu.sg

\section{Pierre Y. Noël}

National Museum of Natural History, UMR CNRS-UPMC-MNHN 5178, Department of Habitats and Aquatic Populations, P.O. Box 53, 57 rue Cuvier, F-75231 Paris cedex 05, France pnoel@mnhn.fr 
Ruth M. O'Riordan

Department of Biological Sciences, National University of Singapore, 14 Science Drive 4, 117543, Singapore \& Department of Zoology, Ecology and Plant Science, University College Cork, Distillery Fields, North Mall, Cork, Ireland r.oriordan@ucc.ie

\section{Vadim E. Panov}

Faculty of Biology and Soil Science, St. Petersburg State University, Universitetskaya nab. 7-9, 199034 St. Petersburg, Russia

rbic@zin.ru; vpanov@aquaticinvasions.ru

\section{Christopher A. Pearl}

USGS Forest and Rangeland Ecosystem Science Center, 3200 SW Jefferson Way, Corvallis, OR 97331, USA

christopher_pearl@usgs.gov

Giovanni Pedicillo

Department of Cellular and Environmental Biology, University of Perugia, Via Elce di Sotto, 06123 Perugia, Italy

pedicillog@yahoo.it

\section{Miguel Petrere Jr}

São Paulo State University, Júlio de Mesquita Filho, UNESP, Biosciences Institute, Av. 24 A n.1515, Bela Vista, P.O. Box 199, Rio Claro, SP, 13506-900, Brazil

mpetrere@rc.unesp.br

\section{Manfred Pöckl}

Vienna Ecology Centre, Department of Freshwater Ecology, University of Vienna; State Government of Lower Austria Landhausplatz 1, 3109 St. Pölten, Austria

manfred.poeckl@noel.gv.at

\section{Marino Prearo}

Experimental Zooprofilactic Institute of Piedmont, Liguria and Valle d'Aosta, Via Bologna 148, 10154 Torino, Italy

marino.prearo@izsto.it 
Neil F. Ramsay

Department of Biological Sciences, National University of Singapore, 14 Science Drive 4, Singapore 117543 \& Department of Zoology, Ecology and Plant Science, University College Cork, Distillery Fields, North Mall, Cork, Ireland r.ramsay@ucc.ie

Riccardo Scalera

Via Torcegno 49 V1 A2, 00124 Roma, Italy

scaleric@tin.it,riccardo.scalera@alice.it

Dawn M. Scott

School of Biosciences, Hatherly Laboratories, Prince of Wales Road, University of Exeter, Exeter, EX4 4PS, UK

d.m.scott@exeter.ac.uk

Tamara A. Shiganova

Shirshov Institute of Oceanology of the Russian Academy of Science, 36 Nakhimov Avenue, 117997 Moscow, Russia

shiganov@ocean.ru

Catherine Souty-Grosset

UMRCNRS 6556 Génétique et Biologie des Populations de Crustacés, University of Poitiers, 40 Avenue du recteur Pineau, 86022 Poitiers cedex, France catherine.souty@univ-poitiers.fr

Andrew Storey

School of Animal Biology (M092), The University of Western Australia, 35 Stirling Highway, Crawley, W.A. 6009, Australia

awstorey@cyllene.uwa.edu.au

Gabrielle Thiébaut

LIEBE, CNRS, Campus Bridoux, Paul Verlain University, Metz, Avenue du Général Delestraint, 57070 Metz, France

thiebaut@univ-metz.fr 
Jozef Tomeček

Comenius University, Faculty of Natural Sciences, Department of Ecology, Mlynská dolina B-2, 84215 Bratislava, Slovakia

tomecek@sopsr.sk

\section{Alessandra Visentin}

Department of Biology, University of Padova, Via U. Bassi 58/BIG, 35121 Padova, Italy

alessandravisentin@libero.it

\section{Eva Willén}

Department of Environmental Assessment, Swedish University of Agricultural Sciences, P.O. Box 7050, SE-750 07 Uppsala, Sweden

eva.willen@ma.slu.se

Rod W. Wilson

School of Biosciences, Hatherly Laboratories, Prince of Wales Road, University of Exeter, Exeter, EX4 4PS, UK

r.w.wilson@exeter.ac.uk

David A. Wright

University of Maryland, Center for Environmental Science, Chesapeake Biological Laboratory, Solomons, MD 20688, USA wright@cbl.umces.edu 


\section{Foreword}

Q: Why are some environments more vulnerable to invasion than others?

A: Environments? In the first volume of this series you asked which species traits coincide with good invaders ... now environments!

Q: Sure, if traits are not terribly powerful predictors alone, I thought that perhaps species traits and kinds of systems might somehow covary. What do you think?

A: Well that depends.

Q: Depends on what?

A: That depends too.

Freshwater environments are islands of sorts. Lakes, rivers, streams and wetlands are uniquely bounded and discrete at one readily apparent scale of observation, the basin or channel boundary. It comes as no surprise, then, that ecological thought has been so strongly influenced by research conducted within the confines of systems so easily circumscribed. Yet, aquatic and terrestrial habitats are inexorably coupled such that this boundary, while substantial at some scales or levels of organization, vanishes at others. This fact is well illustrated by the cascading or indirect effects induced by non-native species that readily traverse the interface between land and water.

Biological invasions represent the latest threat to the integrity of freshwater ecosystems worldwide, systems that are already impacted in massive fashion by human activity. Based on the number of documented and potential extinctions, the freshwater fauna of North America are experiencing an extinction rate that is five times that of the terrestrial environment. ${ }^{\mathrm{i}}$ While unrelenting habitat modification and resource exploitation directly accounts for many of these species losses, exotic species have surely played a role in what is an unprecedented

${ }^{\text {i }}$ Ricciardi, A. and J.B. Rasmussen. 1998. Extinction rates of North American Freshwater Fauna. Conserv. Biol. 13: 1220-1222. 
episode of extinction in real time. Humans, however, are not safe in their role as the dominant purveyors of extinction. Ecosystem modification is often accompanied by increased susceptibility to invasion, and once established, exotic species are fully capable of changing all the rules driving system organization.

This is a broad-based volume, crafted with the widest possible brush strokes. Francesca Gherardi set out to create a volume that not only addressed the phenomenon of biological invasions in freshwater systems, but that also reflects the very breadth of contemporary approaches employed to understand the threats posed by the global movement of species. Here, the reader will find specificity and generality, application as well as theory, along with the sociopolitical implications and response to a global crisis. In a very real sense, this volume represents everything invasions.

James Drake Series Editor 


\section{Preface}

Nowadays we live in a very explosive world, and while we may not know where or when the next outburst will be, we might hope to find ways of stopping it or at any rate damping down its force.

Charles Elton 1958

In the past few decades, it has become clear to scientists and policy-makers that the human-mediated introduction of species - meaning the deliberate or accidental introduction into the wild of microbes, fungi, plants, and animals, including genetically modified organisms (GMOs) outside their natural range of distribution - is the main driver of biodiversity change (Sala et al. 2000). Acting often in concert with other anthropogenic alterations to the environment, such as changes in land use, climate, nitrogen deposition, and atmospheric $\mathrm{CO}_{2}$, the effects on global biodiversity are expected to increase quickly with time in both extent and intensity.

Changes in the natural distribution of species should not, in general, be viewed as abnormal events (Lodge 1993). They are commonplace in nature, often occurring over the course of geological times in association with climate change (Graumlich and Davis 1993). But only rare events, usually associated with unusual climatic conditions such as storms, may induce the dispersal of species to habitats previously beyond their natural dispersal capabilities (MacIsaac et al. 2001). Human actions are more frequent and powerful. Such actions have greatly increased the temporal rate at which species disperse and the distances they traverse, accomplishing in a few decades something that could have never been accomplished by the means of natural events alone (Lodge 1993).

Since their earliest migrations, humans have contributed to the spread of organisms, always carrying them and their propagules over long distances. But the frequency of human-induced introductions of species and the consequent 
risks associated with them have augmented exponentially in the recent past in concert with the fast growth of the human population and with the rapid escalation of our potentials to alter the environment. Large numbers of people are today traveling faster and farther, and more and more goods and materials are being traded among nations and continents (Pimentel et al. 2002), creating a "New Pangaea" (Mooney 1998 cited by Rosenzweig 2001). All these factors combined have produced burgeoning rates of non-indigenous species (NIS) in every ecosystem that has been monitored. Over 480,000 NIS have been introduced into the varied ecosystems on earth (Pimentel et al. 2002) and have come to dominate about 3\% of the ice-free surface over the last 500 years (Mack 1985). Their prevalence is exacerbated by climatic changes that in their turn favor the natural spread and proliferation of NIS (Dukes and Mooney 1999, Carlton 2000, Cowx 2002). The combined effect of the spread of cosmopolitan species and the extinction or range contraction of regional and endemic indigenous organisms often results in the "mingling" of the taxonomic composition of once disparate biota (Olden et al. 2004). This phenomenon is inevitably leading to the "homogenization" (McKinney and Lockwood 1999) or "McDonaldization" of the biosphere (Lövei 1997) that will characterize, it has been said, the forthcoming "Homogocene" era (Orians 1994 cited by Rosenzweig 2001).

Indeed, several introduced species have been beneficial to humans; species such as corn, wheat, rice, plantation forests, domestic chicken, cattle, and others provide now more than 98\% of the world's food supply (Ewel et al. 1999, Pimentel et al. 2002). Many cause minimal environmental impact, as predicted by the oft-cited "tens rule" (Williamson and Fitter 1996). So, the fraction of the introduced species that cause problems is small, but their impact could be very serious. These species have the potential of becoming numerically and ecologically prominent; they spread from the point of introduction and are often able to dominate indigenous populations and communities (Kolar and Lodge 2001); they may profoundly and adversely affect indigenous species, ecosystem processes, economic interests, and public health (e.g. Ricciardi et al. 1998). In sum, they may turn out to be invasive. Their effects that justify alarm include biodiversity loss at the level of species, large reduction in the lower (genetic) and higher (generic) levels of biodiversity, changes in ecosystem functions, alteration of the ecosystem services provided to humans, aesthetic modifications of landscapes, direct costs to industries, damage to crops and forests, and the spread of human diseases, such as HIV and West Nile virus (Mack et al. 2000). Also, deliberate introductions made to solve local or regional problems may be responsible for serious ecological and economic consequences, the so-called Frankenstein Effect (Moyle et al. 1986). The costs they inflict form a hidden but onerous "tax" on many goods and services and the damages they cause are often irrevocable: biological invaders act as biological pollutants that, unlike chemicals, reproduce and spread autonomously, over great distances, 
and can adapt to changing conditions. Their impacts may be continuously increasing over time, even when their introduction ceases.

Since the 1980s, studies of NIS have expanded greatly, resulting in a flood of scientific publications and in the foundation of two invasion-focused journals, Diversity and Distribution (Blackwell Publishing) in 1998 and Biological Invasions (Kluwer-Springer) in 1999, this growth reflecting the rise in popularity that the discipline of invasion biology has gained as an appealing area of research among ecologists. The overall number of published articles appears, however, to be significantly biased towards terrestrial invaders; invasive events occurring in freshwater systems have been most often neglected or analyzed in a few regional contexts or for a small number of paradigmatic species.

In this book, the identity, distribution, and impact of freshwater NIS will be examined, as well as the dynamics of their invasion. Rather than providing a broad and comprehensive review of the issue, Biological Invaders in Inland Waters focuses on old and new invaders and also raises questions and opens perspectives that will be of stimulus for further research. Inland waters will be taken here as meaning rivers, lakes, and reservoirs. Coastal lagoons, saline lakes, estuaries, and low salinity seas such as the Baltic, will be mentioned when appropriate.

The ultimate, ambitious purpose of the book is to help define a more general framework for our knowledge of invasions in fresh waters. Such a framework will be indispensable to the planning of a science-based management program. Inspiration for this effort came from the International Workshop, "Biological Invasions in Inland Waters" (INWAT), held in Florence (Italy) between 5 and 7 May 2005 and made possible by support from Ente Cassa di Risparmio di Firenze, the Italian Ministry of University and Scientific Research (MIUR), the University of Florence, the Provinces of Arezzo, Firenze, Grosseto, Pisa, and Pistoia, and the International Association of Astacology. The INWAT Workshop was a necessary addendum of the final meeting (Florence, 2-5 May 2005) of the European network CRAYNET ("European crayfish as keystone species - linking science, management and economics with sustainable environmental quality", coordinator Catherine Souty-Grosset) (Fifth EU Framework).

This volume benefited greatly from the collaboration - and patience - of the authors and the numerous reviewers. Heartfelt thanks are directed to Jim Drake, who was the first supporter of the project, to Geoff Sanders for his careful linguistic revision, to Claudia Angiolini for her editorial help, and to Suzzanne Mekking and Martine van Bezooijen at Springer for their ability to transform a dream in a printed volume.

F.G.

Florence, Italy

November 2006 


\section{REFERENCES}

Carlton, J. T. 2000. Global change and biological invasions in the oceans. Pages 31-53 in H. A. Mooney and R. J. Hobbs, editors. Invasive species in a changing world. Island Press, Covelo, CA.

Cowx, I. G. 2002. Analysis of threats to freshwater fish conservation: past and present challenges. Pages 201-220 in M. J. Collares-Pereira, I. G. Cowx, and M. M. Coelho, editors. Conservation of freshwater fishes: options for the future. Blackwell Science, Oxford, UK.

Dukes, J. S. and H. A. Mooney. 1999. Does global change increase the success of biological invaders? Trends in Ecology and Evolution 14, 135-139.

Elton, C. S. 1958. The ecology of invasions by animals and plants. University of Chicago Press, Chicago, IL, Edition 2000.

Ewel, J. J., D. J. O’Dowd, J. Bergelson, C. C. Daehler, C. M. D’Antonio, D. Gomez, D. R. Gordon, R. J. Hobbs, A. Holt, K. R. Hopper, C. E. Hughes, M. Lahart, R. R. B. Leakey, W. G. Lee, L. L. Loope, D. H. Lorence, S. M. Louda, A. E. Lugo, P. B. Mcevoy, D. M. Richardson, and P. M. Vitousek. 1999. Deliberate introductions of species: research needs. BioScience 49, 619-630.

Graumlich, L. J. and M. B. Davis. 1993. Holocene variation in spatial scales of vegetation pattern in the upper Great Lakes. Ecology 74, 826-839.

Kolar, C. S. and D. M. Lodge. 2001. Progress in invasion biology: predicting invaders. Trends in Ecology and Evolution 16, 199-204.

Lodge, D. M. 1993. Biological invasions: lessons for ecology. Trends in Ecology and Evolution 8, 133-137.

Lövei, G. L. 1997. Global change through invasion. Nature (London) 388, 627-628.

MacIsaac, H. J., I. A. Grigorovich, and A. Ricciardi. 2001. Reassessment of species invasion concepts: the Great Lakes basin as a model. Biological Invasions 3, 405-416.

Mack, R. N. 1985. Invading plants: their potential contribution to population biology. Pages 127-142 in J. White, editor. Studies on plant demography. Academic, London, UK.

Mack, R. N., D. Simberloff, W. M. Lonsdale, H. Evans, M. Clout, and F. A. Bazzaz. 2000. Biotic invasions: causes, epidemiology, global consequences, and control. Ecological Applications 10, 689-710.

McKinney, M. L. and J. L. Lockwood. 1999. Biotic homogenization: a few winners replacing many losers in the next mass extinction. Trends in Ecology and Evolution 14, 450-453.

Moyle, P. B., H. W. Li, and B. A. Barton. 1986. The Frankenstein Effect: impact of introduced fishes on native fishes in North America. Pages 415-426 in R. H. Strond, editor. Fish culture in fisheries management. American Fisheries Societies, Bethesda, MD.

Olden, J. D., N. L. Poff, M. R. Douglas, M. E. Douglas, and K. D. Fausch. 2004. Ecological and evolutionary consequences of biotic homogenization. Trends in Ecology and Evolution 19, 18-24.

Pimentel, D., S. McNair, J. Janecka, J. Wightman, C. Simmonds, C. O'Connell, E. Wong, L. Russel, J. Zern, T. Aquino, and T. Tsomondo. 2002. Economic and environmental threats of alien plant, animal, and microbe invasions. Pages 307-329 in D. Pimentel, editor. Biological invasions: economic and environmental costs of alien plant, animal, and microbe species. CRC Press, Boca Raton, FL. 
Ricciardi, A., R. J. Neves, and J. B. Rasmussen. 1998. Impending extinctions of North American freshwater mussels (Unionida) following the zebra mussel (Dreissena polymorpha) invasion. Journal of Animal Ecology 67, 613-619.

Rosenzweig, M. 2001. The four questions: what does the introduction of exotic species do to diversity? Evolutionary Ecology Research 3, 361-367.

Sala, O. E., F. S. Chapin III, J. J. Armesto, R. Berlow, J. Bloomfield, R. Dirzo, E. HuberSanwald, L. F. Huenneke, R. B. Jackson, A. Kinzig, R. Leemans, D. Lodge, H. A. Mooney, M. Oesterheld, N. L. Poff, M. T. Sykes, B. H. Walker, M. Walker, and D. H. Wall. 2000. Global biodiversity scenarios for the year 2100. Science 287, 17701774.

Williamson, M. and A. Fitter. 1996. The varying success of invaders. Ecology 77, $1666-1670$.

F.G. wishes to thank the friends and colleagues who acted as reviewers:

Michael Adams, Angelo Antonio Agostinho, Carles Alcaraz, Fernando Alonso Gutiérrez, Giorgio Bavestrello, João Bernardo, Roberto Berti, Giuseppe Boitani, Loïc Bollache, Marco Bologna, Hugo Coops, Gordon Copp, Stephen Corn, Claudia Corti, Alan Covich, Ian Cowx, Bill Daniels, Jaimie Dick, Natham Dorn, Cédric d'Udekem d'Acoz, Frauke Ecke, Jim Fetzner, Jordi Figuerola, John Foster, Michael Fox, Emili Garcia-Berthou, Cristina Giacoma, Folco Giusti, Stephan Gollasch, Joanna Grabowska, Michal Grabowski, Manuela Gualtieri, Joseph Heller, David Holdich, Pierre Horwitz, Jeoffry Howard, Mark Hutchinson, John Jackson, Krzysztof Jazdzewski, Ladd Johnson, Frank Kligenstein, Vladimír Kováč, Daniel Larson, Thomas Lauer, Erni Leppäkoski, Sandro Lovari, Luca Luiselli, Hugh MacIsaac, Alexandra Marçal Correia, Tracy McCollin, Marit Mjerde, Noel Morrissy, Ilona Musko, Erin Muths, Stefan Nehring, Annamaria Nocita, Francesco Nonnis-Marzano, Sergej Olenin, Vadim Panov, Gad Perry, George Phiri, Manfred Pöckl, Mark Ponniah, Giovanni Principato, Wolfang Rabitsch, Philip Rainbow, Sanjeevi Rajagopal, Julian Reynolds, Nicoletta Riccardi, Karl-Otto Rothhaupt, Jordi Sala, Giuseppe Simone, Patrik Stenroth, Gabrielle Thiébaut, Pietro Giorgio Tiscar, Marco Vannini, Marcel Veldhuis, Karen Veverica, Anna Vila-Gispert, Hartwell Welsh, Dudley Williams, Sergio Zerunian. 